\title{
Sensory and microbiological quality assessment of fried snacks produced from ripe and unripe plantain fruits (Musa paradisiaca) fortified with Vigna unguiculata (L.) Walp (cowpea)
}

\author{
Isaac Babatunde OLUWALANA \\ Department of Food Science and Technology, Federal University of Technology, P.M.B 704, Akure, Ondo \\ State, Nigeria. \\ E-mail: ioluwalana2002@yahoo.com; Tel:Tel: 234-8033976209
}

\begin{abstract}
The sensory and microbiological properties of fried snack balls produced from slurries of ripe and unripe plantain fruits supplemented with cowpea were investigated. The main objective is to increase the utilization of plantain in production of nutritious snacks, while observing the impact of cowpea fortification on sensory and microbial qualities of the product. Matured, wholesome, ripe and unripe plantain fruits, cowpea and other ingredients used in this study were obtained from Oba Adesida market in Akure, Ondo State, Nigeria. The plantain pulp and dehulled cowpea were milled into slurries and mixed in the ratios of: 100:0, 90:10, 80:20, 70:30 and 0:100 respectively. The mixtures were then properly whipped with the other ingredients into batter at the ratios of $200 \mathrm{~g}$ sample $+160 \mathrm{ml}$ water (slurry), $36 \mathrm{~g}$ pepper : $36 \mathrm{~g}$ onion and $8 \mathrm{~g}$ salt as recommended by McWatters (2001) before frying at $140{ }^{\circ} \mathrm{C}$ for $10 \mathrm{mins}$ and cooled to about $30{ }^{\circ} \mathrm{C}$. The snacks were then analyzed for microbiological and sensory properties. Results of sensory analysis showed the samples with 90:10 for unripe plantain: cowpea ratio and 80:20 for ripe plantain: cowpea ratio, to be the most acceptable products. There were visible growth of mesophillic bacteria on fresh and as well with fungi on samples stored at $28 \pm 2{ }^{\circ} \mathrm{C}$ and $70 \%$ RH for 24-48 hours. No growth was observed for Staphylococcus aureus, Escherichia coli and Coliform bacteria. It can therefore be concluded that the plantain snack balls are as highly perishable as the cowpea (akara) balls and therefore require additional preservatives if they are to be wholesome beyond 24 hours.

(c) 2014 International Formulae Group. All rights reserved.
\end{abstract}

Keywords: Supplementation, ingredients, slurry, frying, akara, nutritious.

\section{INTRODUCTION}

A snack is a portion of food often smaller than a regular meal, generally eaten between meals. Akara is a Nigerian snack that is made from ground beans, mixed with seasonings into a batter and deep fried. It is similar to Ojojo and Mosa and can be eaten at any time of the day. Snacking is a passion and snack foods are sold everywhere and may be eaten at every meal time as well as in-between meals. A snack should be balanced nutritionally, healthy, easy to eat, provide quick energy and should be of great taste (Giami et al., 2003; Odedeji and Oyeleke, 2011).

Many ready-to-eat foods (snacks) are regarded as 'potentially hazardous' as they can easily support the growth of pathogenic 
(food poisoning) bacteria and must therefore be kept at certain safe temperatures to minimize the growth of these pathogens that may be present in the food or to prevent the formation of toxins in the foods (Oluwalana et al., 2011; Ikya et al., 2013). There is a wide variety of ready-to-eat foods. These include, but are not limited to sandwiches, kebabs, sushi, takeaway foods and bakery products. Ready-to-eat foods usually include a number of ingredients which may or may not be cooked (Giami et al., 2003; Odedeji and Oyeleke, 2011).

Plantain (Musa paradisiaca) is a rhizomatous perennial crop used as a source of starchy staple for millions of people in Nigeria (Adeniyi, et al., 2006; Oluwalana, 2010). Mature plantain pulp is very rich in iron, potassium, vitamin $\mathrm{A}$ and ascorbic acid but low in protein. It also contains $32 \%$ carbohydrate, $1 \%$ protein, $0.02 \%$ fat, $60 \%$ water, some vitamins and mineral elements (Adegboyega, 2006; Chikwendu, 2007; Oluwalana and Oluwamukomi, 2010). The fruit is consumed mainly in Nigeria as boiled, fried or as snacks in form of chips, dodo Ikire, or as the popular roasted delicacy known as "bole" accompanied with fish, etc. It can also be processed into more durable products such as flour that can be stored for later use (Oluwalana and Oluwamukomi, 2011).

Cowpea is high in protein and this gives it a major advantage for use in supplementation of carbohydrate foods particularly in African diets. Cowpea is rich in lysine and its chemical composition is similar to that of most edible legumes. It contains about $24 \%$ protein, $62 \%$ soluble carbohydrates, and small amounts of other nutrients. The use of cowpea in fortifying plantain is important for the following reasons: they make substantial contributions to the energy needs, as well as major dietary protein, vitamin and mineral sources in the plantain products (McWatters, 2001). The aim of this study is therefore to determine the organoleptic and microbiological qualities of fried snacks produced from plantain fruits fortified with cowpea.

\section{MATERIALS AND METHODS Materials}

Matured, wholesome (firm ripe and unripe) plantain fruits, cowpea, vegetable oil (Turkey) and ingredients (pepper, onion, salt) for this study were obtained from Oba Adesida market in Akure, Ondo State, Nigeria. The tools used included knife, deep fryer (MC-DF 1023 China), blender (MC-BL 1230 China), spoon and bowls.

\section{Methods \\ Preparation of raw materials}

Matured fingers of plantain (firm ripe and unripe) were washed, peeled and milled with water at a ratio of 1:0.8 respectively. The cowpea was carefully cleaned to remove adhering soil and extraneous matters from the seed, sorted to remove defective ones from the lot. The cleaned seeds were soaked in potable water to soften the coat for easy removal of the coat before being milled with water at the ratio of 1:0.8 in a blender (MC-BL 1230 China). The plantain and the bean slurries were then proportioned as follows: 90:10, $80: 20,70: 30$ respectively while the $100 \%$ plantain and $100 \%$ bean slurries served as controls.

\section{Production of plantain/cowpea snack balls}

The plantain/cowpea slurry was properly mixed, whipped severally (4-5 minutes) in order to incorporate air using wooden spoon. Other ingredients like pepper, onion and salt were added in the ratio of $200 \mathrm{~g}$ (slurry), $36 \mathrm{~g}$ pepper, $36 \mathrm{~g}$ onion and $8 \mathrm{~g}$ salt. After thorough mixing, the slurry is then scooped to make ball into already heated oil (140-150 ${ }^{\circ} \mathrm{C}$ ) in a deep fryer (MC-DF 1023 China). The scooped balls were turned frequently until deep fried to a golden brown colour. 
Analyses

Microbiological studies of the fried snack
balls

The aerobic plate count was carried out on the fried snack samples according to methods of AOAC (1990). Serial dilution and pour plate techniques were used. Potato Dextrose Agar (PDA) was used for fungi; Nutrient agar (NA) for mesophillic bacteria; Eosin Methylene Blue (EMB) for Escherichia coli; MacConkey Agar (MCA) for Coliform and Mannitol Salt Agar (MSA) for Staphylococcus aureus. Viable colonies were recorded for bacteria as colony forming units (cfu/g) and spore forming units (sfu/g) for fungi.

\section{Sensory evaluation}

The sensory evaluation of the different samples of akara balls were carried using 36 semi-trained panelists who are conventional/constant akara eaters. Ten (10 g) of each sample was placed before each Panelist in a well illuminated cubicle to assess the samples for appearance, colour, taste, flavor, texture and overall acceptability. A 9point hedonic scale which has 9 as "Like extremely", 5 as "Neither Like nor Dislike" and 1 as "Dislike extremely" was used to rate the samples. Data generated were thereafter subjected to statistical analysis to show Panelists' preference.

\section{Statistical analysis}

All determinations were performed in triplicates. The statistical analyses were conducted using one-way ANOVA procedures. Statistical differences were tested for at $\mathrm{p}<0.05$. Duncan's New Multiple-Range Test (DMRT) was used to separate the mean values. All the analyses were done with SPSS (16.0) software.

\section{RESULTS}

The results of the microbiological studies carried out on the fried snack samples are presented in Tables 1, 2 and 3. Table 1 shows microbial growth observed on fresh samples. Bacterial growths were higher in the cowpea samples. There is a correlation between the level of cowpea inclusion and magnitude of growth as higher microbial growth is observed with higher cowpea inclusion. The 100\% cowpea (A100:0) had $1.2 \times 10^{4} \mathrm{cfu} / \mathrm{g}$ while the $100 \%$ ripe plantain snack (R100:0) had $1.0 \times 10^{3} \mathrm{cfu} / \mathrm{g}$ and $3.3 \times 10^{3}$ $\mathrm{cfu} / \mathrm{g}$ for $30 \%$ cowpea inclusion in ripe plantain.

Results in Table 2 show microbial growths in samples after being stored for 24 hours at $28 \pm 2{ }^{\circ} \mathrm{C}$ and $70 \% \mathrm{RH}$. Bacteria and fungi counts were generally much higher in the stored samples than the fresh ones. The magnitude of growth/count followed a similar trend to that observed in fresh samples as samples with higher amounts of cowpea had higher microbial counts.

Table 3 shows the results of microbial counts for samples after 48 hours at $28 \pm 2{ }^{\circ} \mathrm{C}$ and $70 \% \mathrm{RH}$. Bacteria count in sample A100:0 (100\% cowpea as Control) is as high as $8.8 \times 10^{5} \mathrm{cfu} / \mathrm{g}$ while the $100 \%$ ripe and unripe plantain ( R100:0 and U100:0) had $1.2 \times 10^{4} \mathrm{cfu} / \mathrm{g}$ and $1.6 \times 10^{4} \mathrm{cfu} / \mathrm{g}$ counts respectively. The result showed a clear trend of higher microbial counts with increase in cowpea inclusion in samples. This could be due to the higher protein, vitamin and mineral contents of cowpea compared to plantain. These counts are obviously much higher than those for fresh samples but not too different from samples kept for $24 \mathrm{hrs}$ at the stipulated storage conditions. The appearance of fungi growth on all samples after $24 \mathrm{hrs}$. storage is a clear evidence that both plantain and cowpea snack balls cannot keep beyond 24 hrs without a deliberate inclusion of a preservative to the snacks.

The results of sensory evaluation of the fried snack samples are presented in Tables 4 and 5. Table 4 shows the sensory attributes of cowpea and unripe plantain snack balls. The attributes scored by the panelists were appearance, taste, colour, flavour, texture and overall acceptability. Sample A100:0 (Cowpea) was scored best in all the parameters and was significantly different $(p<0.05)$ from the plantain samples except for texture of A100:0, U100:0 and U70:30 that were in close range. The unripe plantain 
samples were not significantly different from each other in terms of appearance, taste, colour, flavour and overall acceptability.

Table 5 shows the sensory attributes of cowpea and ripe plantain balls. R100:0 was rated lowest in terms of appearance (5.33) and colour (4.73). A100:0 was rated best in all the parameters. Amongst the other samples, the 90:10 and 80:20 plantains: cowpea ratios were rated next to the $100 \%$ cowpea sample. This indicates that $10-20 \%$ cowpea inclusion in plantain could be an acceptable mix for the plantain-cowpea snack.

Table 1: Microbial counts in freshly prepared akara balls made from cowpea and plantain blends.

\begin{tabular}{lccccc}
\hline Sample & $\begin{array}{l}\text { Mesophillic } \\
\text { Bacteria } \\
\text { (cfu/g) }\end{array}$ & $\begin{array}{c}\text { E. coli count } \\
\text { (cfu/g) }\end{array}$ & $\begin{array}{c}\text { Staph. aureus } \\
\text { (cfu/g) }\end{array}$ & $\begin{array}{c}\text { Coliform count } \\
\text { (cfu/g) }\end{array}$ & $\begin{array}{c}\text { Fungi count } \\
\text { (sfu/g) }\end{array}$ \\
\hline $\mathrm{A} 100: 0$ & $1.2 \times 10^{4}$ & $\mathrm{NP}$ & $\mathrm{NP}$ & $\mathrm{NP}$ & $\mathrm{NP}$ \\
$\mathrm{U} 100: 0$ & $1.3 \times 10^{3}$ & $\mathrm{NP}$ & $\mathrm{NP}$ & $\mathrm{NP}$ & $\mathrm{NP}$ \\
$\mathrm{U} 90: 10$ & $1.6 \times 10^{3}$ & $\mathrm{NP}$ & $\mathrm{NP}$ & $\mathrm{NP}$ & $\mathrm{NP}$ \\
$\mathrm{U} 80: 20$ & $2.3 \times 10^{3}$ & $\mathrm{NP}$ & $\mathrm{NP}$ & $\mathrm{NP}$ & $\mathrm{NP}$ \\
$\mathrm{U} 70: 30$ & $1.0 \times 10^{3}$ & $\mathrm{NP}$ & $\mathrm{NP}$ & $\mathrm{NP}$ & $\mathrm{NP}$ \\
$\mathrm{R} 100: 0$ & $1.0 \times 10^{3}$ & $\mathrm{NP}$ & $\mathrm{NP}$ & $\mathrm{NP}$ & $\mathrm{NP}$ \\
$\mathrm{R} 90: 10$ & $2.0 \times 10^{3}$ & $\mathrm{NP}$ & $\mathrm{NP}$ & $\mathrm{NP}$ & $\mathrm{NP}$ \\
$\mathrm{R} 80: 20$ & $1.6 \times 10^{3}$ & $\mathrm{NP}$ & $\mathrm{NP}$ & $\mathrm{NP}$ & $\mathrm{NP}$ \\
$\mathrm{R} 70: 30$ & $3.3 \times 10^{3}$ & $\mathrm{NP}$ & $\mathrm{NP}$ & $\mathrm{NP}$ & $\mathrm{NP}$ \\
\hline $\mathrm{V}$
\end{tabular}

Values are means of triplicate evaluations. NP = Not Present; A100:0 = Cowpea 100\%;

U100:0 = Unripe plantain 100\% cowpea 0\% ; U90:10 = Unripe plantain 90\% cowpea 10\% ;

U80:20 = Unripe plantain 80\% cowpea 20\%; U70:30 = Unripe plantain 70\% cowpea 30\% ;

R100:0 = Ripe plantain 100\% cowpea $0 \% ;$ R90:10 = Ripe plantain 90\% cowpea 10\%;

R80:20 = Ripe plantain $80 \%$ cowpea $20 \% ; \mathrm{R} 70: 30=$ Ripe plantain $70 \%$ cowpea $30 \%$;

Table 2: Microbial counts in akara balls made from cowpea and plantain blends after $24 \mathrm{hrs}$. storage at $28 \pm 2{ }^{\circ} \mathrm{C}$ and $70 \% \mathrm{RH}$.

\begin{tabular}{lccccc}
\hline Sample & $\begin{array}{c}\text { Mesophillic } \\
\text { Bacteria count } \\
(\mathbf{c f u} / \mathbf{g})\end{array}$ & $\begin{array}{c}\text { E. coli count } \\
(\mathbf{c f u} / \mathbf{g})\end{array}$ & $\begin{array}{c}\text { Staph. aureus } \\
\text { count }(\mathbf{c f u} / \mathbf{g})\end{array}$ & $\begin{array}{c}\text { Coliform } \\
\text { count }(\mathbf{c f u} / \mathbf{g})\end{array}$ & $\begin{array}{c}\text { Fungi count } \\
\text { (sfu/g) }\end{array}$ \\
\hline $\mathbf{A 1 0 0 : 0}$ & $4.2 \times 10^{5}$ & $\mathrm{NP}$ & $\mathrm{NP}$ & $\mathrm{NP}$ & $2.0 \times 10^{3}$ \\
$\mathbf{U 1 0 0 : 0}$ & $5.3 \times 10^{4}$ & NP & NP & NP & $1.0 \times 10^{3}$ \\
$\mathbf{U 9 0 : 1 0}$ & $3.4 \times 10^{4}$ & NP & NP & NP & $1.0 \times 10^{3}$ \\
$\mathbf{U 8 0 : 2 0}$ & $1.8 \times 10^{5}$ & NP & NP & NP & $2.0 \times 10^{3}$ \\
$\mathbf{U 7 0 : 3 0}$ & $6.3 \times 10^{4}$ & NP & NP & NP & $2.0 \times 10^{3}$ \\
$\mathbf{R 1 0 0 : 0}$ & $8.4 \times 10^{4}$ & NP & NP & NP & $3.0 \times 10^{3}$ \\
R90:10 & $1.1 \times 10^{5}$ & NP & NP & NP & $1.0 \times 10^{3}$ \\
$\mathbf{R 8 0 : 2 0}$ & $3.5 \times 10^{5}$ & NP & NP & NP & $4.0 \times 10^{3}$ \\
R70:30 & $2.5 \times 10^{5}$ & NP & NP & NP & $2.0 \times 10^{3}$ \\
\hline
\end{tabular}

Values are means of triplicate evaluations

$\mathrm{NP}=$ Not Present; A100:0 = Cowpea 100\%; U100:0 = Unripe plantain 100\% cowpea 0\%;

U90:10 = Unripe plantain 90\% cowpea 10\% ; U80:20 = Unripe plantain 80\% cowpea 20\%;

U70:30 = Unripe plantain 70\% cowpea 30\% ; R100:0 = Ripe plantain 100\% cowpea 0\%;

R90:10 = Ripe plantain 90\% cowpea 10\%; R80:20 = Ripe plantain $80 \%$ cowpea $20 \%$;

R70:30 = Ripe plantain $70 \%$ cowpea $30 \%$. 
Table 3: Microbial counts in akara balls made from cowpea and plantain blends after storage for 48 hrs at $28 \pm 2{ }^{\circ} \mathrm{C}$ and $70 \% \mathrm{RH}$.

\begin{tabular}{lccccc}
\hline Sample & $\begin{array}{c}\text { Mesophillic } \\
\text { Bacteria count } \\
(\mathbf{c f u} / \mathbf{g})\end{array}$ & $\begin{array}{c}\boldsymbol{E} \text {. coli count } \\
(\mathbf{c f u} / \mathbf{g})\end{array}$ & $\begin{array}{c}\text { Staph. } \\
\text { aureus(cfu/g) }\end{array}$ & $\begin{array}{c}\text { Coliform } \\
\text { count }(\mathbf{c f u} / \mathbf{g})\end{array}$ & $\begin{array}{c}\text { Fungi count } \\
(\mathbf{s f u} / \mathbf{g})\end{array}$ \\
\hline $\mathrm{A} 100: 0$ & $8.8 \times 10^{5}$ & $\mathrm{NP}$ & $\mathrm{NP}$ & $\mathrm{NP}$ & $4.0 \times 10^{3}$ \\
$\mathrm{U} 100: 0$ & $1.6 \times 10^{4}$ & $\mathrm{NP}$ & $\mathrm{NP}$ & $\mathrm{NP}$ & $3.0 \times 10^{3}$ \\
$\mathrm{U} 90: 10$ & $6.4 \times 10^{4}$ & $\mathrm{NP}$ & $\mathrm{NP}$ & $\mathrm{NP}$ & $7.0 \times 10^{3}$ \\
$\mathrm{U} 80: 20$ & $1.1 \times 10^{6}$ & $\mathrm{NP}$ & $\mathrm{NP}$ & $\mathrm{NP}$ & $2.0 \times 10^{3}$ \\
$\mathrm{U} 70: 30$ & $1.1 \times 10^{5}$ & $\mathrm{NP}$ & $\mathrm{NP}$ & $\mathrm{NP}$ & $5.0 \times 10^{3}$ \\
$\mathrm{R} 100: 0$ & $1.2 \times 10^{4}$ & $\mathrm{NP}$ & $\mathrm{NP}$ & $\mathrm{NP}$ & $3.0 \times 10^{3}$ \\
$\mathrm{R} 90: 10$ & $4.3 \times 10^{5}$ & $\mathrm{NP}$ & $\mathrm{NP}$ & $\mathrm{NP}$ & $1.1 \times 10^{3}$ \\
R80:20 & $7.3 \times 10^{5}$ & $\mathrm{NP}$ & $\mathrm{NP}$ & $\mathrm{NP}$ & $6.0 \times 10^{3}$ \\
R70:30 & $5.3 \times 10^{5}$ & $\mathrm{NP}$ & $\mathrm{NP}$ & $\mathrm{NP}$ & $1.3 \times 10^{3}$ \\
\hline
\end{tabular}

$\mathrm{NP}=$ Not Present;

A100:0 = Cowpea 100\%; U100:0 = Unripe plantain 100\% cowpea 0\%;

U90:10 = Unripe plantain 90\% cowpea 10\%; U80:20 = Unripe plantain 80\% cowpea $20 \%$

U70:30 = Unripe plantain 70\% cowpea 30\%; R100:0 = Ripe plantain 100\% cowpea 0\% ;

R90:10 = Ripe plantain 90\% cowpea 10\%; R80:20 = Ripe plantain 80\% cowpea $20 \%$;

$\mathrm{R} 70: 30=$ Ripe plantain $70 \%$ cowpea $30 \%$.

Table 4: Sensory attributes of snacks made from cowpea and unripe plantain blends.

\begin{tabular}{ccccccc}
\hline Sample & Appearance & Colour & Taste & Flavour & Texture & Overall Acceptability \\
\hline A100:0 & $8.07 \pm 0.79^{\mathrm{a}}$ & $8.47 \pm 0.63^{\mathrm{a}}$ & $8.13 \pm 0.83^{\mathrm{a}}$ & $8.40 \pm 0.51^{\mathrm{a}}$ & $7.80 \pm 1.01^{\mathrm{a}}$ & $8.20 \pm 0.56^{\mathrm{a}}$ \\
U100:0 & $6.20 \pm 0.94^{\mathrm{b}}$ & $5.73 \pm 0.79^{\mathrm{c}}$ & $6.33 \pm 1.11^{\mathrm{b}}$ & $6.27 \pm 1.10^{\mathrm{b}}$ & $7.40 \pm 0.91^{\mathrm{a}}$ & $6.53 \pm 074^{\mathrm{b}}$ \\
U90:10 & $6.40 \pm 1.06^{\mathrm{b}}$ & $6.60 \pm 1.05^{\mathrm{b}}$ & $6.40 \pm 1.05^{\mathrm{b}}$ & $6.33 \pm 1.18^{\mathrm{b}}$ & $6.20 \pm 0.68^{\mathrm{b}}$ & $6.93 \pm 0.88^{\mathrm{b}}$ \\
U80:20 & $6.73 \pm 0.88^{\mathrm{b}}$ & $6.80 \pm 1.08^{\mathrm{b}}$ & $6.53 \pm 1.25^{\mathrm{b}}$ & $6.27 \pm 1.16^{\mathrm{b}}$ & $6.73 \pm 1.03^{\mathrm{b}}$ & $6.87 \pm 0.74^{\mathrm{b}}$ \\
U70:30 & $6.73 \pm 0.96^{\mathrm{b}}$ & $6.87 \pm 1.13^{\mathrm{b}}$ & $6.73 \pm 0.70^{\mathrm{b}}$ & $6.80 \pm 0.94^{\mathrm{b}}$ & $7.47 \pm 0.74^{\mathrm{a}}$ & $6.87 \pm 0.92^{\mathrm{b}}$ \\
\hline
\end{tabular}

Values in the same column with different letters in superscript are significantly different at $\mathrm{p}<0.05$

A100:0 = Cowpea 100\%; U100:0 = Unripe plantain 100\% cowpea 0\%;

U90:10 = Unripe plantain 90\% cowpea 10\%; U80:20 = Unripe plantain 80\% cowpea 20\% ;

U70:30 = Unripe plantain $70 \%$ cowpea $30 \%$.

Table 5: Sensory attributes of snacks made from cowpea and ripe plantain blends.

\begin{tabular}{lcccccc}
\hline Sample & Appearance & Colour & Taste & Flavour & Texture & $\begin{array}{c}\text { Overall } \\
\text { Acceptability }\end{array}$ \\
\hline A100:0 & $8.07 \pm 0.96^{\mathrm{a}}$ & $8.07 \pm 0.79^{\mathrm{a}}$ & $8.00 \pm 0.93^{\mathrm{a}}$ & $8.13 \pm 0.63^{\mathrm{a}}$ & $8.00 \pm 0.85^{\mathrm{a}}$ & $8.40 \pm 0.51^{\mathrm{a}}$ \\
$\mathrm{R} 100: 0$ & $5.33 \pm 1.35^{\mathrm{c}}$ & $4.73 \pm 1.98^{\mathrm{c}}$ & $6.80 \pm 1.57^{\mathrm{b}}$ & $7.07 \pm 1.10^{\mathrm{b}}$ & $6.00 \pm 1.56^{\mathrm{b}}$ & $6.40 \pm 1.29^{\mathrm{b}}$ \\
$\mathrm{R} 90: 10$ & $6.47 \pm 1.18^{\mathrm{b}}$ & $6.00 \pm 1.41^{\mathrm{b}}$ & $6.60 \pm 1.50^{\mathrm{b}}$ & $7.20 \pm 1.01^{\mathrm{b}}$ & $6.27 \pm 1.34^{\mathrm{b}}$ & $6.53 \pm 1.46^{\mathrm{b}}$ \\
$\mathrm{R} 80: 20$ & $6.73 \pm 1.10^{\mathrm{b}}$ & $6.67 \pm 1.29^{\mathrm{b}}$ & $6.87 \pm 1.25^{\mathrm{b}}$ & $6.80 \pm 1.26^{\mathrm{b}}$ & $6.73 \pm 1.53^{\mathrm{b}}$ & $6.87 \pm 0.99^{\mathrm{b}}$ \\
R70:30 & $6.73 \pm 0.79^{\mathrm{b}}$ & $6.60 \pm 1.12^{\mathrm{b}}$ & $6.93 \pm 1.28^{\mathrm{b}}$ & $7.07 \pm 1.03^{\mathrm{b}}$ & $6.20 \pm 1.32^{\mathrm{b}}$ & $6.80 \pm 0.94^{\mathrm{b}}$ \\
\hline
\end{tabular}

Values in the same column with different letters in superscript are significantly different at $\mathrm{p}<0.05$;

A100:0 = Cowpea 100\%; R100:0 = Ripe plantain 100\%cowpea 0\%; R90:10 = Ripe plantain 90\% cowpea 10\%;

R80:20 = Ripe plantain $80 \%$ cowpea $20 \%$; R70:30 = Ripe plantain $70 \%$ cowpea $30 \%$. 


\section{DISCUSSION}

Microbiological analysis of fresh and stored ( 24 hrs and 48 hrs) samples

Fresh samples

The results of the total viable count are shown in Table 1. Sample A100:0 had the highest count of mesophillic bacteria while samples U100:0 and R100:0 showed lower values. There is a trend of higher microbial counts for higher incorporation of cowpea. This could be due to availability of more proteins to the organisms as the protein inclusion increases. Ikya et al. (2013) has reported speedy microbial spoilage in cowpea balls (akara) not treated with a preservative (Aframomum danielli). No Coliform, Escherichia coli and Staphylococcus aureus were found in the fresh samples, which is an indication that the samples were completely free from feacal contamination. There was no fungi growth as well.

Samples stored for $24 \mathrm{hrs}$ at $28 \pm 2{ }^{\circ} \mathrm{C}$ and $70 \%$ RH

The results of the microbial counts for samples stored for 24 hours at ambient conditions (Table 2) showed a similar trend to that of fresh samples, except that the figures are higher in the stored samples. This is an indication that the samples have very short shelf life at ambient conditions. Similar trend has been observed by Oluwalana et al. (2011) in their study of the influence of temperature and storage time on microbial and sensory qualities of plantain and its reconstituted dumpling (amala). No growth of Staphylococcus aureus was observed. Fungi growths were however found on all the samples at this storage conditions.

\section{Samples Stored for $48 \mathrm{hrs}$ at $28 \pm 2{ }^{\circ} \mathrm{C}$ and $70 \% \mathrm{RH}$}

The results of microbial counts for samples stored for 48 hours are shown in Table 3. There were increased mesophillic bacteria growths for all the samples indicating that there were increased activities of microorganisms in the samples. As storage days increased, microbial counts also increased (Oluwalana et al., 2011). The increased microbial count could serve as an indication that the samples could be spoilt at the end of the $48^{\text {th }}$ hour and therefore unfit for consumption. No growth was recorded for Staph. aureus. There was also an increased fungi growth for all the samples. However, no visible growth was recorded for $E$. coli and Coliform bacteria indicating that either the water used for the processes was portable or hygienic preparatory procedures were followed.

\section{Sensory Properties of the Fried Snack Samples}

The cowpea samples were rated higher than the plantain samples which is probably due to the fact that the panelists are used to the taste of cowpea balls (akara) which has a unique taste and beany flavor while the plantain samples with their cowpea blends, being new products are probably unfamiliar to the taste panelists.

\section{Conclusion}

The plantain balls are as highly perishable as the akara balls and are unfit for consumption after 24 hours of storage at tropical ambient conditions $\left(28 \pm 2{ }^{\circ} \mathrm{C}\right.$ and $70 \%$ $\mathrm{RH})$. Therefore, only the quantity required for daily consumption need be prepared if no preservative is to be added (Ikya et al., 2013) and in the case of left-over, have to be refrigerated / refried before eating. There is therefore a need for further works on akara ball to investigate the influence of food preservatives on its storage ability.

Sensory results showed preference for the cowpea balls which could be due to the fact that the panelists are used to it while the other samples is relatively new to them. There is therefore a need for orientation of people to new products. The fortification of unripe and ripe plantain balls with $10 \%$ and $20 \%$ cowpea resulted in very acceptable products. It can therefore be concluded that to obtain an acceptable cowpea fortified plantain balls, the fortification should be done at $10 \%$ cowpea inclusion for unripe plantain and $20 \%$ for the ripe ones.

\section{REFERENCES}

Adeniyi TA, Sanni LO, Barimalaa LS, Hart AD. 2006. Determination of 
micronutrients and color variability among new plantain and banana hybrid flour. World J. Chem., 1(1): 23-27.

Adegboyega OK. 2006. Chemical composition of unripe (green) and ripe plantain (Musa paradisiaca). J. Sci. Food Agric., 24(6): 703-707.

Chikwendu NJ. 2007. Chemical composition of 'Akara' (Fried ground bean paste) developed from fermented and germinated ground bean (Kerstingiella georcarpa) and maize (Zea mays) blends. Journal of Agriculture, Food, Environment and Extension, 6(1): 1-8.

Giami SY, Akusu MO, Jaja IR. 2003. Production, organoleptic assessment and nutritional properties of akara from cowpea/maize flour blends. Plant Foods for Human Nutrition, 58: 1-9.

Ikya JK, Nongomin PT, Iorbee A. 2013. Effect of Aframomum danielli on the keeping quality characteristics of akara. Journal of Agriculture and Veterinary Sciences, 5(1): 147-158.

McWatters KH, Hung CYT, Hung YC, Chinnan MS, Phillips RD. 2001. Compositional, Physical and Sensory Characteristics of Akara Processed from Cowpea Paste and Nigerian Cowpea Flour. Journal of Food Quality, 24(1): 53-65.
Odedeji OJ, Oyeleke WA. 2011. Proximate, Physicochemical and organoleptic properties of whole and dehulled cowpea seed flour (Vigna unguiculata). Pakistan Journal of Nutrition, 10(12): 1175-1178.

Oluwalana IB. 2010. Minimizing fruit wastages in Nigeria. International Journal of Agriculture and Food Science, 1(1):77-87.

Oluwalana IB, Oluwamukomi MO. 2010. Changes in Qualities of Ripening Plantain fruits stored at Tropical Ambient Conditions. International Journal of Agriculture and Food Science, 1(1): 203207.

Oluwalana IB, Oluwamukomi MO. 2011. Proximate Composition, Rheological and Sensory Qualities of Plantain Flour blanched under three temperature regimes. African Journal of Food Science, 5(14): 769-774.

Oluwalana IB, Oluwamukomi MO, Fagbemi TN, Oluwafemi GI. 2011. Microbial and Sensory qualities of plantain flour and its reconstituted dumpling (Amala) as influenced by blanching temperature and duration. Journal of Sustainable Technology, 2(2): 70-73. 